\title{
Molecular Detection of Apiosporina morbosa, Causal Agent of Black Knot in Prunus virginiana
}

\author{
J. X. Zhang, W. G. D. Fernando, and W. R. Remphrey, Department of Plant Science, University of Manitoba, \\ Winnipeg, Manitoba, R3T 2N2, Canada
}

\begin{abstract}
Zhang, J. X., Fernando, W. G. D., and Remphrey, W. R. 2005. Molecular detection of Apiosporina morbosa, causal agent of black knot in Prunus virginiana. Plant Dis. 89:815-821.

A specific and sensitive polymerase chain reaction (PCR) assay was developed to detect Apiosporina morbosa, the causal agent of black knot disease on chokecherry, Prunus virginiana (including the cultivar 'Shubert Select'). A pair of A. morbosa-specific forward and reverse primers (AMF and AMR) was designed from the internal transcribed spacer (ITS) regions of $A$. morbosa, preamplified by universal ITS primers ITS1 and ITS4, and compared with the ITS region sequences of Fusarium, Alternaria, Phoma, and Cladosporium species associated with black knots. The primers were tested for their specificity to A. morbosa detection in the PCR assays using DNA derived from 64 pure cultures, including 42 single-spore isolates of A. morbosa and 22 isolates of other fungi, as well as healthy and diseased plant branches collected from the field. A product of $\sim 400 \mathrm{bp}$ was amplified from DNA of all isolates belonging to $A$. morbosa. No product was amplified from DNA of other fungal species, confirming the specificity of the newly designed primers. Within plant tissues, the pathogen was detected at further distances from the edges of knots on thicker branches bearing larger knots compared with thinner branches bearing smaller knots. The PCR assay has shown high sensitivity, needing only 100 fg of the A. morbosa DNA for a reliable PCR amplification with the AMF and AMR primers.
\end{abstract}

Additional keywords: Dibotryon morbosum, 'Shubert Select'

Black knot, caused by the fungus Apiosporina morbosa (Schwein.:Fr.) Arx (syn. Dibotryon morbosum (Schwein.:Fr.) Theiss. \& Syd.), is a serious disease of Prunus spp. $(8,14,16,21)$. Fungal ascospores usually infect young branches during spring and cause rough greenish brown-to-black spindle-shaped galls (black knots) on twigs and branches $(13,16)$. The pathogen overwinters in infected branches of Prunus spp. as mycelia on which pseudothecia develop (10). It has a long latent period on the plant. Generally, knots appear on infected twigs or branches 1 year after infection (13). A wide variety of both wild and cultivated species of Prunus can be infected by the fungus. In Ontario, the disease has occurred on many wild hosts such as Prunus americana Marsh., $P$. virginiana L., and $P$. pensylvanica L. (9). Plum trees such as the European plum $(P$. domestica L.) and the Japanese plum ( $P$.

Corresponding author: W. G. D. Fernando

E-mail: D_Fernando@Umanitoba.ca

Current address of J. X. Zhang: USDA/ARS, Division of Plant Pathology and Microbiology, Department of Plant Sciences, University of Arizona, Tucson 85721.

Accepted for publication 21 March 2005.

DOI: 10.1094/PD-89-0815

(C) 2005 The American Phytopathological Society salicina Lindl.) are also susceptible to black knot in eastern Canada (13). Significant production losses of sour cherry have been observed in the Niagara Peninsula in Ontario, Canada (13). In western Canada, black knot disease has occurred mainly on wild and cultivated chokecherry ( $P$. virginiana L.) and pin cherry (P. pensylvanica L.) (21). Disease incidence has recently increased in nurseries and city plantings of the ornamental purple-leaved chokecherry cultivar $P$. virginiana 'Shubert Select' in the Prairie Provinces of Canada. Previous investigations showed that humidity and temperature are the most important factors governing the epidemiology of black knot disease in Prunus spp. (9). Release of ascospores depends especially on rainfall and temperature during early spring $(8,13)$. Koch (8) demonstrated that removal of knots in late winter is effective for controlling black knot disease on plum trees. Excellent control can also be obtained by spray application of lime sulfur on plum trees (8), and recent research demonstrated that fungicides such as captan were also effective against black knot on plum and sour cherry (14). However, efficacy of captan seemed to depend on the application time. An application of captan on sour cherry in late May reduced black knot disease incidence to $0.4 \%$, whereas applications of captan after early June were ineffective (14).
Despite the effectiveness of fungicides, control is difficult once black knot disease becomes epidemic on trees. If the disease can be diagnosed at early development stages, management strategies such as chemical sprays can be implemented before epidemics develop. In addition, although A. morbosa is the causal agent of black knot, there are several other fungi from different fungal genera, such as Fusarium, Penicillium, Phomopsis, Alternaria, Phoma, and Cladosporium, that are associated with knots, primarily as saprophytes (9). This makes isolation and identification of the pathogen more difficult from infected plant tissues using traditional culture methods. Therefore, a rapid and accurate method for the specific detection of the causal agent of black knot in plant materials is needed for management of this disease. Traditional isolation and identification of $A$. morbosa can be timeconsuming, thereby limiting management options in the nursery industry. A rapid diagnostic assay will aid in pathogen identification and lead to more effective management practices. The polymerase chain reaction (PCR)-based techniques for species-specific detection have become very popular (3). Compared with traditional diagnostic methods, the PCR-based techniques have certain advantages. For example, they do not always require culture of the target organisms prior to detection. Moreover, they are very sensitive, rapid, and specific $(5,7,17)$. The objectives of this research were to (i) develop primers for specific detection of A. morbosa, and (ii) apply the primers in PCR reactions to rapidly detect the pathogen from infected plant tissues in field-grown plants.

\section{MATERIALS AND METHODS}

Source of isolates. Samples of black knots were collected from different geographic locations in Canada and in the United States, and from different host species, mostly wild chokecherry ( $P$. virginiana) and its cultivar 'Shubert Select' (Table 1). Two methods were used to isolate A. morbosa from knots. First, fungi were isolated according to the methods of Koch (10). Knots were washed and moistened under running tap water for $30 \mathrm{~min}$. Pieces $(0.5 \mathrm{~cm})$ from each knot sample were surface-sterilized using $10 \%$ commercial bleach $(0.5 \% \mathrm{NaHCl})$ for $4 \mathrm{~min}$. After rinsing with sterile water three times, five pieces were placed on petri plates 
Table 1. Apiosporina morbosa isolates and other fungal genera from black knots on chokecherry and pin cherry trees in Canada

\begin{tabular}{|c|c|c|c|c|c|c|}
\hline \multirow[b]{2}{*}{ Isolate $^{\mathrm{b}}$} & \multirow[b]{2}{*}{ Species $^{c}$} & \multirow[b]{2}{*}{ Host } & \multirow[b]{2}{*}{ Origin } & \multirow{2}{*}{$\begin{array}{c}\text { Year of } \\
\text { isolation }\end{array}$} & \multicolumn{2}{|c|}{ PCR product with ${ }^{\mathrm{a}}$} \\
\hline & & & & & ITS1/ITS4 & AMF/AMR \\
\hline 3DF1 & Apiosporina morbosa & 'Shubert Select' & Jeffries Nurseries, $\mathrm{MB}^{\mathrm{d}}$ & 2003 & + & + \\
\hline 3DF2 & A. morbosa & 'Shubert Select' & Jeffries Nurseries, MB & 2003 & + & + \\
\hline 3DF5 & A. morbosa & 'Shubert Select' & Jeffries Nurseries, MB & 2003 & + & + \\
\hline 3DF7 & A. morbosa & 'Shubert Select' & Jeffries Nurseries, MB & 2003 & + & + \\
\hline 3DF8 & A. morbosa & 'Shubert Select' & Jeffries Nurseries, MB & 2003 & + & + \\
\hline 3DF9 & A. morbosa & 'Shubert Select' & Jeffries Nurseries, MB & 2003 & + & + \\
\hline 3DF10 & A. morbosa & 'Shubert Select' & Jeffries Nurseries, MB & 2003 & + & + \\
\hline $3 \mathrm{DF} 23$ & A. morbosa & 'Shubert Select' & John Forsyth, Winnipeg, MB & 2003 & + & + \\
\hline 3 DF 25 & A. morbosa & 'Shubert Select' & John Forsyth, Winnipeg, MB & 2003 & + & + \\
\hline 3DF 50 & A. morbosa & 'Shubert Select' & Abbotsfield, Winnipeg, MB & 2003 & + & + \\
\hline 3DF 53 & A. morbosa & 'Shubert Select' & Abbotsfield, Winnipeg, MB & 2003 & + & + \\
\hline 3DF 58 & A. morbosa & 'Shubert Select' & Hochman, Winnipeg, MB & 2003 & + & + \\
\hline 3DF 59 & A. morbosa & 'Shubert Select' & Lanyon, Winnipeg, MB & 2003 & + & + \\
\hline 3DF 60 & A. morbosa & 'Shubert Select' & Lanyon, Winnipeg, MB & 2003 & + & + \\
\hline $3 \mathrm{DF} 63$ & A. morbosa & 'Shubert Select' & Wales Ave. Regina, SK & 2003 & + & + \\
\hline 3DF 66 & A. morbosa & 'Shubert Select' & Wales Ave. Regina, SK & 2003 & + & + \\
\hline 3DF 67 & A. morbosa & 'Shubert Select' & Wales Ave. Regina, SK & 2003 & + & + \\
\hline 3DF 68 & A. morbosa & 'Shubert Select' & Wales Ave. Regina, SK & 2003 & + & + \\
\hline 3DF135 & A. morbosa & Wild chokecherry & Riding Mountain National Park-1, MB & 2003 & + & + \\
\hline 3DF136 & A. morbosa & Wild chokecherry & Riding Mountain National Park-1, MB & 2003 & + & + \\
\hline 3DF143 & A. morbosa & Wild chokecherry & Riding Mountain National Park-2, MB & 2003 & + & + \\
\hline 3DF148 & A. morbosa & Wild chokecherry & Riding Mountain National Park-2, MB & 2003 & + & + \\
\hline 3DF152 & A. morbosa & Wild chokecherry & Riding Mountain National Park-2, MB & 2003 & + & + \\
\hline 3DF154 & A. morbosa & Wild chokecherry & Riding Mountain National Park-3, MB & 2003 & + & + \\
\hline 3DF156 & A. morbosa & Wild chokecherry & Riding Mountain National Park-3, MB & 2003 & + & + \\
\hline 2DF3 & A. morbosa & Wild chokecherry & Waterton, $\mathrm{AB}$ & 2002 & + & + \\
\hline 2DF7 & A. morbosa & 'Shubert Select' & University of Manitoba, MB & 2002 & + & + \\
\hline 2DF22 & A. morbosa & Wild chokecherry & Bird's Hill, Winnipeg, MB & 2002 & + & + \\
\hline 2DF48 & A. morbosa & 'Shubert Select' & Superior, Wisconsin, USA & 2002 & + & + \\
\hline 2DF52 & A. morbosa & P. pensylvanica & Lac Seul, ON & 2002 & + & + \\
\hline 2DF55 & A. morbosa & $P$. pensylvanica & Lac Seul, ON & 2002 & + & + \\
\hline 2DF57 & A. morbosa & 'Shubert Select' & Morden, MB & 2002 & + & + \\
\hline 2DF59 & A. morbosa & 'Shubert Select' & Morden, MB & 2002 & + & + \\
\hline 2DF60 & A. morbosa & Wild chokecherry & Waterton, $\mathrm{AB}$ & 2002 & + & + \\
\hline 2DF62 & A. morbosa & Wild chokecherry & Morris, MB & 2002 & + & + \\
\hline 2DF64 & A. morbosa & 'Shubert Select' & Morden, MB & 2002 & + & + \\
\hline 2DF65 & A. morbosa & Wild chokecherry & Waterton, $\mathrm{AB}$ & 2002 & + & + \\
\hline 2DF67 & A. morbosa & Wild chokecherry & Morris, MB & 2002 & + & + \\
\hline 2DF68 & A. morbosa & 'Shubert Select' ' & Superior, Wisconsin, USA & 2002 & + & + \\
\hline 2DF77 & A. morbosa & P. pensylvanica & Lac Seul, ON & 2002 & + & + \\
\hline 2DF78 & A. morbosa & P. pensylvanica & Lac Seul, ON & 2002 & + & + \\
\hline ATCC15085 & A. morbosa & - & American Type Culture Collection, USA & 2002 & + & + \\
\hline S1 & Fusarium, sp-1 & 'Shubert Select' & Jeffries Nurseries, MB & 2003 & + & - \\
\hline $\mathrm{S} 2$ & $F . \mathrm{sp}-1$ & 'Shubert Select' & John Forsyth, Winnipeg, MB & 2003 & + & - \\
\hline S3 & $F$. sp-1 & 'Shubert Select' & Abbotsfield, Winnipeg, MB & 2003 & + & - \\
\hline S4 & F. sp-2 & Wild chokecherry & Riding Mountain National Park-1, MB & 2003 & + & - \\
\hline S5 & F. sp-2 & 'Shubert Select' & Jeffries Nurseries, MB & 2003 & + & - \\
\hline S6 & F. sp-3 & Wild chokecherry & Riding Mountain National Park-1, MB & 2003 & + & - \\
\hline S7 & F. sp-3 & Wild chokecherry & Riding Mountain National Park-2, MB & 2003 & + & - \\
\hline S8 & F. sp-4 & Wild chokecherry & Riding Mountain National Park-3, MB & 2003 & + & - \\
\hline S9 & Alternaria sp-1 & Wild chokecherry & Riding Mountain National Park-1, MB & 2003 & + & - \\
\hline S10 & A. $\mathrm{sp}-2$ & Wild chokecherry & Riding Mountain National Park-1, MB & 2003 & + & - \\
\hline S11 & Phoma sp-1 & 'Shubert Select' & John Forsyth, Winnipeg, MB & 2003 & + & - \\
\hline $\mathrm{S} 12$ & P. sp-1 & 'Shubert Select' & Abbotsfield, Winnipeg, MB & 2003 & + & - \\
\hline S13 & $P . \mathrm{sp}-1$ & 'Shubert Select' & Jeffries Nurseries, MB & 2003 & + & - \\
\hline S14 & P. sp-1 & Wild chokecherry & Morris, MB & 2003 & + & - \\
\hline S15 & P. sp-1 & Wild chokecherry & Bird's Hill, Winnipeg, MB & 2003 & + & - \\
\hline S16 & P. sp-2 & 'Shubert Select' & Jeffries Nurseries, MB & 2003 & + & - \\
\hline S17 & $P$. sp-2 & Wild chokecherry & Riding Mountain National Park-1, MB & 2003 & + & - \\
\hline S18 & P. sp-2 & Wild chokecherry & Riding Mountain National Park-2, MB & 2003 & + & - \\
\hline S19 & P. sp-3 & 'Shubert Select' & Morden, MB & 2003 & + & - \\
\hline S20 & Cladosporium sp-1 & Wild chokecherry & Riding Mountain National Park-3, MB & 2003 & + & - \\
\hline $\mathrm{S} 21$ & C. sp-2 & 'Shubert Select' & Jeffries Nurseries, MB & 2003 & + & - \\
\hline S22 & C. $\mathrm{sp}-2$ & 'Shubert Select' & Jeffries Nurseries, MB & 2003 & + & - \\
\hline
\end{tabular}

${ }^{a}+$ and - indicate presence and absence of the approximately 550- and 400-bp DNA fragments amplified by the universal primer pair ITS1 + ITS4 and the Apiosporina morbosa-specific primer pair AMF + AMR, respectively.

b Representative isolates collected from different geographic locations and two host species, Prunus virginiana (wild chokecherry and 'Shubert Select' chokecherry) and P. pensylvanica. Their internal transcribed spacer (ITS) region amplifications with the ITS1 and ITS4 primers and the amplified products with the AMF and AMR primers are shown on the agarose gels in Figures 1 and 3, respectively.

${ }^{\mathrm{c}}$ Isolates with the same number in the same genus share the identical ITS sequence.

${ }^{\mathrm{d}} \mathrm{MB}=$ Manitoba; $\mathrm{SK}=$ Saskatchewan; $\mathrm{AB}=$ Alberta; $\mathrm{ON}=$ Ontario. 
containing $1.5 \%$ water agar. Fungal colonies formed around diseased tissues on the water agar plate in 2 to 3 days at room temperature $\left(22^{\circ} \mathrm{C}\right)$. From the edge of each colony, a piece of mycelium was transferred onto potato dextrose agar plates (PDA) (Difco Laboratories, Detroit, MI) containing $100 \mathrm{ppm}$ streptomycin sulfate (Sigma, Oakville, ON) to reduce bacterial contamination. The PDA plates were incubated for a week, and single conidial spores were transferred onto new PDA plates under a microscope with $\times 400$ magnification to obtain single conidial spore isolates. In the second method, galls were surface-sterilized with $10 \%$ commercial bleach and washed with sterile water. Fresh epidermal tissues with fungal stroma were removed from the gall using a scalpel and macerated in a few drops of sterile water on a slide using a round-ended glass rod. The macerate was streaked on water agar plates and incubated for $24 \mathrm{~h}$ at room temperature. Single germinating ascospores were marked on plates under the microscope and were transferred to PDA plates to obtain pure single ascospore isolates. In addition, all other fungi associated with knots were isolated, purified, and stored for DNA analysis together with $A$. morbosa isolates. A list of the A. morbosa isolates, other black knot-associated fungal isolates from Fusarium, Phoma, Alternaria, and Cladosporium, and their sources is shown in Table 1. An isolate of A. morbosa (strain ATCC15085) was obtained from the American Type Culture Collection to compare morphological characteristics and sequences of the internal transcribed spacer (ITS) region with $A$. morbosa strains isolated from knots in Canada.

DNA extraction. Mycelia of each $A$. morbosa isolate were grown in a flask with $75 \mathrm{ml}$ of potato dextrose broth (PDB) (Difco Laboratories). The PDB in the flask was inoculated with a $0.5-\mathrm{ml}$ suspension of approximately $10^{6}$ spores of an isolate per $\mathrm{ml}$. The flasks were incubated at room temperature for $24 \mathrm{~h}$ without agitation. Mycelia of other gall-associated fungi were produced using a similar culture method, except that the flasks were incubated at room temperature for 3 to 4 days with agitation. Mycelia were harvested by vacuum filtration through two layers of sterilized Miracloth (Calbiochem, CN Biosciences, La Jolla, CA) and rinsed twice with sterile water, then stored at $-80^{\circ} \mathrm{C}$ until lyophilized. DNA of isolates was extracted essentially by the method described by Lodhi et al. (12), except that polyvinylpyrrolidone was not used in the extraction procedure. All DNA extracts were quantified using a spectrophotometer and adjusted to a final concentration of 5 $\mathrm{ng} \mathrm{\mu l}^{-1}$ for PCR analysis.

Amplification of ITS region and primer design. The 42 A. morbosa isolates and 22 isolates of Fusarium, Phoma, Alternaria, and Cladosporium, collected from different geographic locations and host species in Canada and the United States, were used in PCR amplification of the ITS regions (Table 1). The universal primers ITS1 (5'-TCCGTAGGTGAACCTGCGG-3') and ITS4 (5'-TCCTCCGCTTATTGATATGC-3') (20) were used to amplify the region spanning the $3^{\prime}$ end of the $18 \mathrm{~S}$ rRNA gene, internal transcribed spacer 1 (ITS1), the 5.8 rRNA gene, ITS2, and the $5^{\prime}$ end of the 28 rRNA gene. PCR was conducted in a $25-\mu$ l reaction volume. Each reaction contained approximately 25 ng of template DNA, $2.5 \mu \mathrm{l}$ of $10 \times$ PCR buffer, 1 unit of Taq DNA polymerase (recombinant) (Invitrogen Life Technologies, Burlington, ON, Canada), $100 \mathrm{mM}$ Tris- $\mathrm{HCl}$ (pH 8.0), $500 \mathrm{mM} \mathrm{KCl}, 0.5 \mu \mathrm{M}$ each of the ITS1 and ITS4 primers, 1.5 $\mathrm{mM} \mathrm{MgCl}_{2}$, and $0.2 \mathrm{mM}$ each of dNTPs (Invitrogen Life Technologies). The temperature profile of the PCR was 40 cycles consisting of denaturing at $94^{\circ} \mathrm{C}$ for $2 \mathrm{~min}$, annealing at $55^{\circ} \mathrm{C}$ for $1 \mathrm{~min}$, and extension at $72^{\circ} \mathrm{C}$ for $2 \mathrm{~min}$. A final extension at $72^{\circ} \mathrm{C}$ for $10 \mathrm{~min}$ followed. A negative control (no template DNA) was used in every experiment to test for presence of contamination in reagents. Amplified products were electrophoresed on $1.4 \%$ agarose gels containing ethidium bromide at $0.5 \mu \mathrm{g} \mathrm{ml}^{-1}$ with $1 \times$ TBE running buffer. A 100-bp DNA ladder (Invitrogen Life Technologies) was included on each gel as a molecular size standard. Since fragments amplified with the ITS1 and ITS4 primers from $A$. morbosa isolates and other fungal isolates were similar in size, specific primers needed to be designed for the detection of A. morbosa. To achieve this goal, all PCR products amplified with the ITS1 and ITS4 primers were purified using the High Pure PCR Product Purification Kit (Roche Applied Science, Penzberg, Germany) and were sent to the University Core DNA and Protein Services, University of Calgary, Alberta, Canada, for sequencing. The ITS sequences of $A$. morbosa isolates were aligned with those of all other fungi asso- ciated with black knots using the multiple sequence alignment software, CLUSTAL W (1.82) (EMBL-EBL, European Bioinformatics Institute). Two regions specific to A. morbosa were identified and used to design an A. morbosa-specific forward primer (AMF) and a reverse primer (AMR). The two primers were synthesized by Invitrogen Life Technologies.

Specificity and sensitivity of the $A$. morbosa-specific primers. All DNA samples of $42 \mathrm{~A}$. morbosa isolates and 22 isolates of other fungal genera were used in PCR amplification for the specificity test of the AMF and AMR primers (Table 1). To test the sensitivity of the specific primers for the A. morbosa detection, 1 fg to 10 ng of serial dilutions of DNA of the $A$. morbosa isolate $3 \mathrm{DF} 1$ were used as templates for PCR amplification. The PCR conditions with the AMF and AMR primers were identical to those described above in the PCR reactions with the ITS1 and ITS4 primers, except that the annealing temperature was $58^{\circ} \mathrm{C}$ rather than $55^{\circ} \mathrm{C}$. The PCR reaction with the ITS1 and ITS4 primers was performed as the positive control to compare the size of the product generated from the AMF and AMR primers and ensure that the template DNA was amplifiable.

PCR amplification from diseased plants. To compare spread of pathogen in diseased branches of different size, the $A$. morbosa primers AMF and AMR were tested against DNA samples extracted from diseased branches of 'Shubert Select' chokecherry within two diameter categories (Table 2). Diameters of the first set of 10 diseased branches ranged from 0.4 to $0.7 \mathrm{~cm}$, on which black knots were $0.5-1 \times$ $1-3 \mathrm{~cm}$ in size, whereas diameters of another set of 10 branches ranged from 2 to $2.5 \mathrm{~cm}$, on which knots were $3-4 \times 4-7 \mathrm{~cm}$ in size. The branches that produced only one knot on each were selected for tissue sampling, and branches from healthy trees served as the controls. The tissue samples on diseased branches were obtained from black knots, as well as 1, 3, 5, 7, 9, and 11 $\mathrm{cm}$ from the edges of knots (Table 2). DNA was extracted from the plant tissues using the method described by Lodhi et al. (12). The PCR was conducted with the AMF and AMR primers using the conditions described in the above reactions.

\section{RESULTS}

Isolation of A. morbosa. In 2002 and 2003, a total of 41 single-spore isolates of

Table 2. Detection of Apiosporina morbosa from diseased branches of Prunus virginiana 'Shubert Select'

\begin{tabular}{lccccccccc}
\hline \multirow{2}{*}{$\begin{array}{l}\text { Branch } \\
\text { diam. }(\mathbf{c m})\end{array}$} & $\begin{array}{c}\text { Knot size } \\
(\mathbf{c m})\end{array}$ & \multicolumn{6}{c}{ PCR assay with DNA extracted at different distances (cm) from edges of knots } \\
\cline { 2 - 10 } & Knot tissues & $\mathbf{1}^{\text {a }}$ & $\mathbf{3}$ & $\mathbf{5}$ & $\mathbf{7}$ & $\mathbf{9}$ & $\mathbf{1 1}$ & Healthy branch \\
\hline $0.4-0.7$ & $0.5-1 \times 1-3$ & $10 / 10^{\mathrm{b}}$ & $9 / 10$ & $1 / 10$ & $0 / 10$ & $0 / 10$ & $0 / 10$ & $0 / 10$ & $0 / 10$ \\
$2-2.5$ & $3-4 \times 4-7$ & $10 / 10$ & $10 / 10$ & $10 / 10$ & $6 / 10$ & $0 / 10$ & $0 / 10$ & $0 / 10$ & $0 / 10$ \\
\hline
\end{tabular}

${ }^{a}$ Distance from edge of knot where plant tissues were removed.

${ }^{\mathrm{b}}$ Number of branches in which 400-bp polymerase chain reaction (PCR) fragment was detected / total number of branches assayed. 
A. morbosa and 22 isolates from the Fusarium, Phoma, Alternaria, and Cladosporium species associated with black knots were isolated and placed in our collection (Table 1). All isolates were used for DNA extraction, PCR reactions with the ITS1 and ITS4 primers, and the specificity test of the AMF and AMR primers.

Design of PCR primers. An approximately 550-bp DNA fragment of ITS region was PCR amplified from all A. morbosa isolates and other fungal isolates using the ITS1 and ITS4 primers (Table 1 and Fig. 1). The sequenced ITS region data showed that all isolates of $A$. morbosa including the ATCC15085 isolate had the identical ITS sequence, but a few isolates (2DF3, 2DF64, and 3DF54) had mutations in one to two sites (bases) (data not shown). ITS sequences of five A. morbosa representative isolates, including type isolate ATCC15085, have been submitted to GenBank. The accession numbers are AF493982, AF493983, AF493984, AY165751, and AY166451 (ATCC15085), respectively. For other gall-associated fungi, some isolates from the same genus had identical sequences, and thus sequences of 22 isolates of other fungi were classified into 11 different sequence categories. To design A. morbosa-specific primers, the sequence of the ITS region of
A. morbosa isolate 3DF1 (Table 1), which represented sequences of $A$. morbosa and had an identical sequence to ATCC15085, was aligned with the 11 different ITS sequences of other fungal species. Sequencing data showed that isolates of A. morbosa had significantly different sequences from those of Fusarium spp., Phoma spp., and Alternaria spp. at the region used for designing the specific primers (data not shown). However, two isolates of Cladosporium spp. (C. sp-1 and $C$. sp-2) had high sequence similarity to $A$. morbosa at the region used for designing the primers (Fig. 2). The A. morbosa-specific primers were designed to specifically dis-

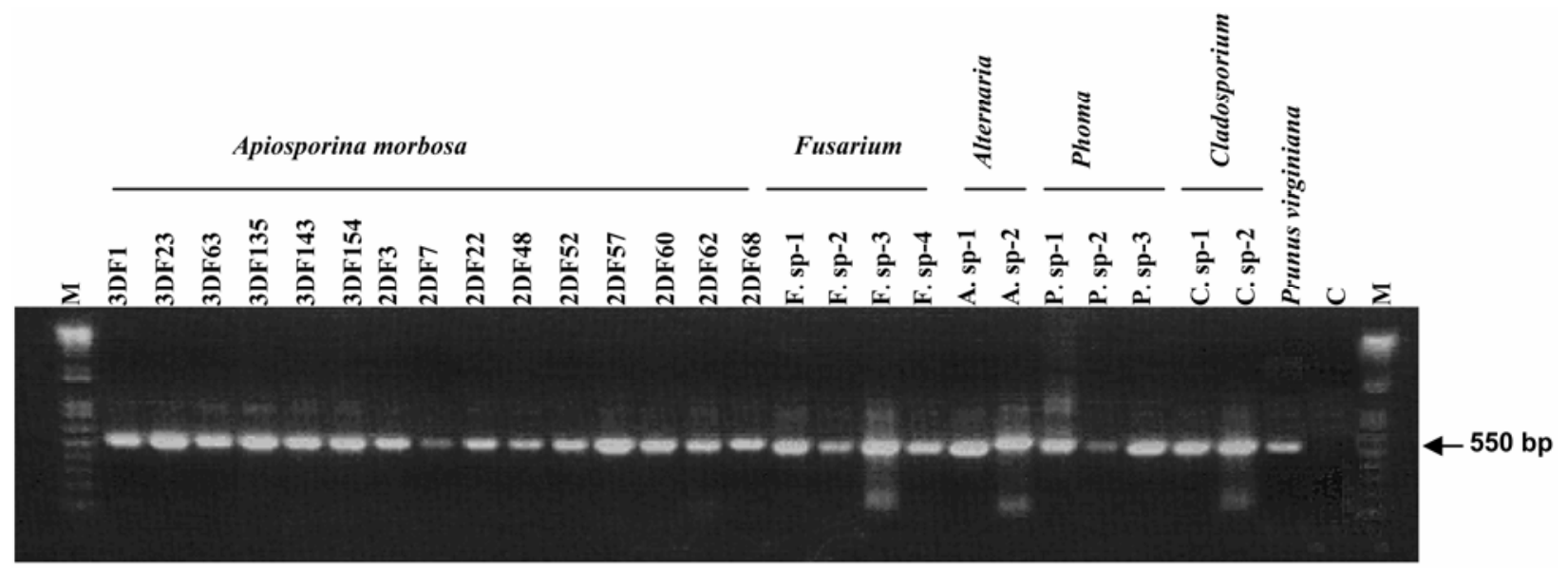

Fig. 1. An agarose gel showing bands amplified from the of rDNA with the primer pair ITS1 and ITS4 from 15 representative isolates of Apiosporina morbosa, 11 isolates of Fusarium, Alternaria, Phoma, and Cladosporium species associated with black knots, and healthy plants of Prunus virginiana 'Shubert Select'. $\mathrm{M}=100$-bp DNA ladder. $\mathrm{C}=$ negative control.
A. morbosa
C. $\mathrm{sp}-1$
C. $\mathrm{sp}-2$
A. morbosa
C. $\mathrm{sp}-1$
C. $\mathrm{sp}-2$
A. morbosa
C. $\mathrm{sp}-1$
C. $\mathrm{sp}-2$
A. morbosa
C. $\mathrm{sp}-1$
C. $\mathrm{sp}-2$
A. morbosa
C. sp-1
C. sp-2
A. morbosa
C. $\mathrm{sp}-1$
C. $\mathrm{sp}-2$
A. morbosa
C. $\mathrm{sp}-1$
C. $\mathrm{sp}-2$

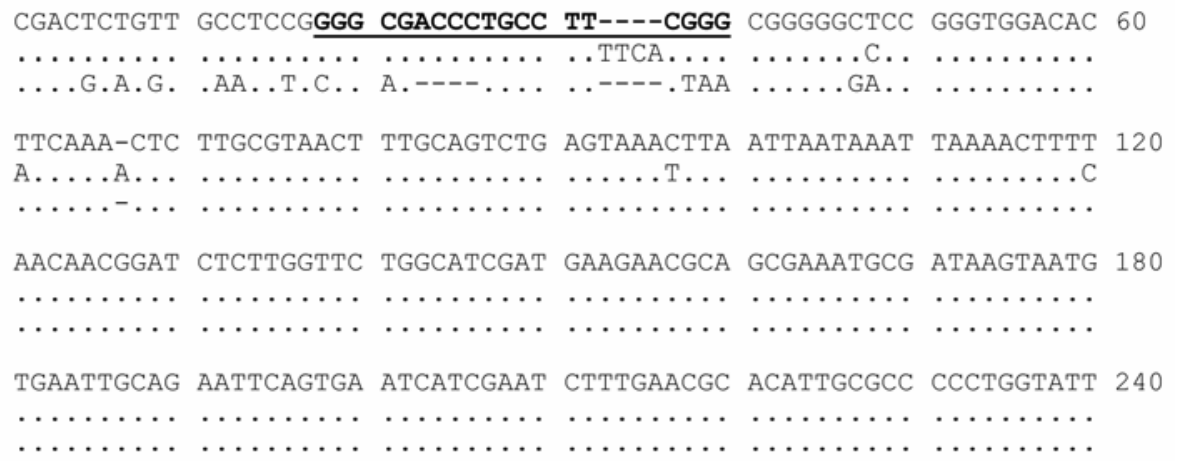

CCGGGGGGCA TGCCTGTTCG AGCGTCATTT CACCACTCAA GCCTCGCTTG GTATTGGGCA 300

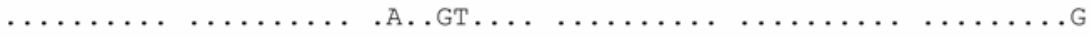

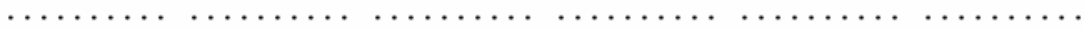

Fig. 2. Sequence alignment of the partial rDNA internal transcribed spacer (ITS) sequences of Apiosporina morbosa (isolate 3DF1) and two Cladosporium isolates ( $C$. sp-1 and $C$. sp-2) that have high similarity in sequence to A. morbosa. The A. morbosa-specific primers (AMF and AMR) were designed according to the two underlined bold regions. The ITS sequences of the Fusarium, Phoma, and Alternaria species were not aligned because they are significantly different in their ITS sequences from A. morbosa. 
criminate against these two isolates. Therefore, the newly designed primers would differentiate $A$. morbosa from all other fungi, including Cladosporium spp. Two 19-bp sequences, 5'-GGGCGACCCTGCCTTCGGG-3' and 5'-TACGGCGTAGCCTCCCGAA- $3^{\prime}$, were identified in the ITS sequence of $A$. morbosa based on which pair of potential A. morbosa-specific primers, 5'-GGGCGACCCTGCCTTCGGG-3' and 5'-ATGCCGCATCGGAGGGCTT-3', were synthesized to serve as the A. morbosa forward (AMF) and reverse (AMR) primers, respectively (Fig. 2).

Specificity and sensitivity of the AMF and AMR primers. In specificity tests, 42 isolates of $A$. morbosa and 22 isolates from other fungal genera were examined in PCR reactions with the specific primers AMF and AMR. Only isolates of A. morbosa yielded a single PCR product approximately $400 \mathrm{bp}$ in size when amplified with the AMF and AMR primers (Table 1 and Fig. 3). Isolates of Fusarium, Phoma, Alternaria, and Cladosporium associated with black knots as well as DNA of healthy plants, did not yield this product with the AMF and AMR primers (Table 1 and Fig. 3). A range of DNA concentrations of the A. morbosa isolate 3DF1 was tested to determine the sensitivity of the PCR assay with the AMF and AMR primers. For the reliable PCR amplification with the AMF and AMR primers, $100 \mathrm{fg}$ to $10 \mathrm{ng}$ of pure DNA from A. morbosa was sufficient (Fig. 4). No products were produced from the negative control.

Detection of $A$. morbosa from diseased plant tissues. In order to test the viability of the AMF and AMR primers when applied to clinical samples, the PCR assays were conducted with the specific primer pairs for detecting the pathogen from diseased tissues of black knots and plant tissues at different distances from the edge of knots. A single PCR product approximately $400 \mathrm{bp}$ in size was detected from diseased tissues of knots and infected tissues up to $3 \mathrm{~cm}$ from edges of black knots on branches 0.4 to $0.7 \mathrm{~cm}$ in diameter (Table 2 and Fig. 5). Although most of the PCR product was detected in plant tissues within $1 \mathrm{~cm}$ from the edges of black knots, one of the 10 branches had the PCR product $3 \mathrm{~cm}$ from the edge of the knot. No amplified products were detected in plant tissues beyond $3 \mathrm{~cm}$ from the edge of knots in the 0.4 to $0.7 \mathrm{~cm}$ diameter branches. In contrast, in the branches 2 to $2.5 \mathrm{~cm}$ in diameter, all samples had the single PCR product detected within $3 \mathrm{~cm}$ and over half within $5 \mathrm{~cm}$ from edge of knots (Table 2 and Fig. 5). No product was detected in the tissues of healthy branches of any diameter.

\section{DISCUSSION}

In this study, we developed a pair of the A. morbosa-specific primers, AMF and AMR, which were used in PCR reactions to detect A. morbosa, the pathogen of black knot in Prunus spp. These PCR assays had very high specificity. They detected the specific fragment from all $A$. morbosa isolates tested, and no specific product was detected with this pair of primers from other fungi associated with black knots, nor from healthy plants. Practical tests done on diseased plants with the primers showed that the PCR assays detected the pathogen in infected plant tissues in the presence of other black knot-

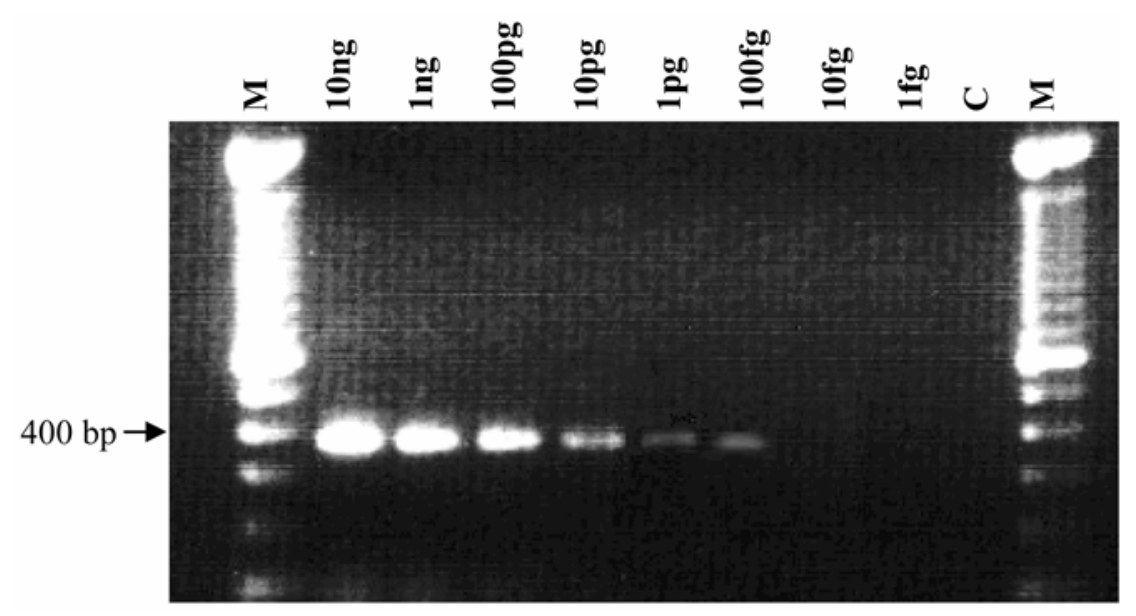

Fig. 4. An agarose gel showing sensitivity of the Apiosporina morbosa-specific primer pair AMF and AMR using a series of pure DNA dilutions from isolate 3DF1 as templates. $\mathrm{M}=100$-bp ladder. $\mathrm{C}=$ negative control.

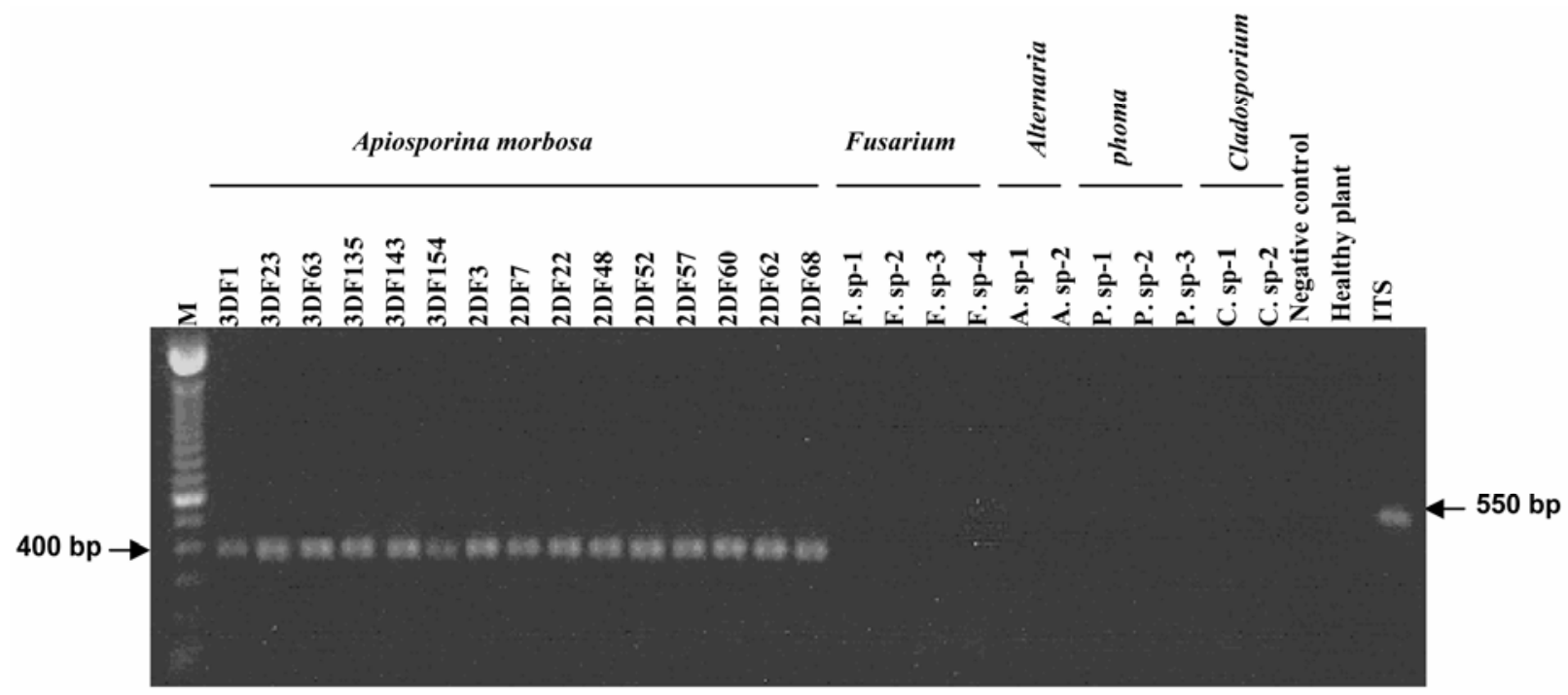

Fig. 3. An agarose gel showing a specific band amplified by polymerase chain reaction (PCR) amplification with the AMF and AMR primers from the Apiosporina morbosa isolates. DNA templates were extracted from 15 representative isolates of $A$. morbosa, 11 isolates of other fungal species with different sequences of internal transcribed spacer (ITS) of rDNA (Fusarium, Alternaria, Phoma, and Cladosporium associated with black knots) (Table 1), and a healthy plant of Prunus virginiana 'Shubert Select'. M is a 100-bp DNA ladder. The 550-bp ITS product was amplified with primers ITS1 and ITS4 from A. morbosa isolate 3DF1 and served as a control of size compared with the 400 -bp product amplified with primers AMF and AMR from the Apiosporina morbosa isolates. 
associated fungi. The PCR assay had high fragment with $100 \mathrm{fg}$ of DNA. To our knowledge, this is the first report of development of specific PCR primers for detection of A. morbosa. tion of pathogens relies on the sensitivity of PCR primers specific to the target pathogen. Several strategies have been used to develop specific PCR primers for randomly amplified polymorphic DNA (RAPD) markers were commonly used to develop specific primers. Recently, RAPD markers have been used successfully to design specific primers for detection of Stachybotrys elegans from soil (17) and Monilinia fructicola from sweet cherry fruits (4). Second, specific genes also can be used to develop specific primers for identification of target pathogens. For example, specific nested primers for detection of the aflatoxin-producing fungi $A s$ pergillus flavus and $A$. parasiticus from grains and food were successfully developed by the omt-1 gene involved in aflatoxin biosynthesis (15). Third, ITS regions of rDNA have been widely used to design specific primers for identification of plant pathogens $(1,6,7,21)$. The ITS regions are less conserved than RNA gene subunits, perhaps because they have no apparent functions (2). Therefore, there is relatively a rapid evolution in the ITS regions of rDNA, and thus high variation. It is reported that differences in ITS regions exist between closely related species and sometimes within species $(18,19)$. This makes the ITS region a good candidate for developing specific PCR primers. In addition, fungal genomes. Therefore, PCR assays that amplify ITS regions of rDNA should be more sensitive than those that amplify single-copy genes. Because of these features of the ITS regions, the $A$. morbosa-specific sensitivity, and it detected the specific

The reliability of a PCR assay for detecidentification of plant pathogens. First, rDNA is present in multiple copies in most

primers were designed using the ITS regions of rDNA in the present research.

Unlike with other fungi, it is difficult to obtain pigment-less DNA samples from $A$. morbosa isolates. At the beginning of this study, we cultured the isolates of $A$. morbosa in PDB with shaking for 3 to 4 days. Although a sufficient amount of mycelia could be harvested by this method, all DNA samples extracted from these mycelium samples were brownish, probably because mycelia were too old and too many brown conidial spores were produced. PCR reactions using this type of DNA could be affected by pigment in the pathogen DNA. To eliminate pigment in DNA, we harvested only young mycelia for DNA extraction. To accomplish this, conidial spores were spread on the surface of PDB in a flask. The flask was held at room temperature for $24 \mathrm{~h}$ without any agitation. A young mycelium mat was formed after 24-h incubation. The DNA extracted from these mycelia was colorless and of higher quality.

The positive results obtained from asymptomatic tissues proximal to A. morbosa galls suggest that the PCR test is a sensitive diagnostic tool for early fungal pathogen detection in trees. PCR tests from tissues distal to galls and from noninfected stems were negative for A. morbosa. In addition, we found that the pathogen was detected at further distances from the edges of knots in thicker branches bearing larger knots compared with thinner branches bearing smaller knots. This may be related to time of pathogen infection. Thicker branches with larger knots may have been infected by the pathogen several years earlier, resulting in mycelia spreading further from infection sites. This result supports the conclusion drawn from a previous histological analysis that mycelia spread further from larger galls than from smaller ones (10).

This study was initiated to develop a pair of primers based on the ITS regions

A

B

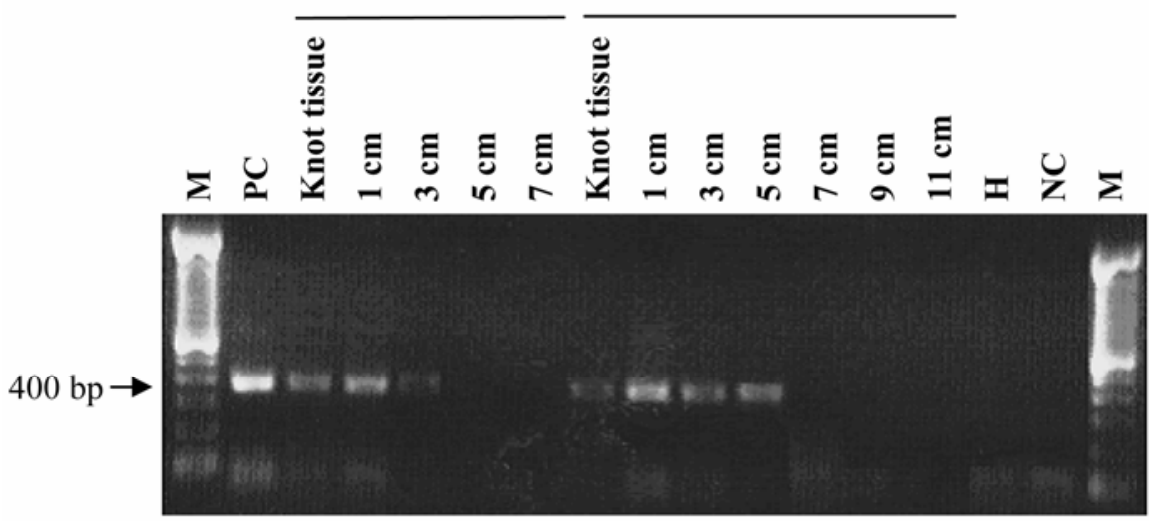

Fig. 5. An agarose gel showing the specific band amplified from Apiosporina morbosa with the AMF and AMR primers from diseased branches. DNA samples were isolated from black knots and infected plant tissues at different distances from edges of black knots on branches 0.4 to $0.7 \mathrm{~cm}$ in diameter (A), and branches 2 to $2.5 \mathrm{~cm}$ in diameter (B). $\mathrm{M}=100$-bp ladder. $\mathrm{PC}=$ positive control with pure DNA from isolate $3 \mathrm{DF} 1 . \mathrm{H}=\mathrm{DNA}$ from healthy plant. $\mathrm{NC}=$ negative control. for rapid and specific detection of $A$. morbosa. We successfully tested young twigs with small black knots using the designed primers. Although the primers had good specificity and sensitivity for detecting the pathogen, more testing needs to be done in cities and nurseries where chokecherry is produced and grown in the landscape. In particular, if the pathogen can be detected early, increased efficacy of the chemical sprays may be achieved. Therefore in future work, it would be beneficial to widen the scope of plant tissue sampling to include tissues from different infection stages, tissues carrying spores, tissues at initial infection sites with no visible symptoms, and slightly swelled tissues and knots prior to production of fruiting bodies. Successful tests from these stages will greatly benefit the making of sound, economical management strategies for this disease. For example, transplanting rooted 'Shubert Select' chokecherry cuttings infected by the black knot pathogen is a likely source of disease spread in nurseries. If the cuttings are at the latent infection stage, the pathogen can be found through molecular detection before commercial sales are made from the nursery. The cuttings can be treated with fungicides or discarded at the nursery so that introduction of disease into new areas may be reduced. Similarly, if ornamental chokecherry trees infected by the fungus in towns, cities, or nurseries can be diagnosed through PCR with the specific primers at the initial disease development stage, an appropriate management practice such as chemical spray and removal of diseased branches can be done before black knot disease becomes epidemic, and thus risk of disease epidemics will be reduced greatly.

In the present study, the PCR assays were not quantitative and only detected the presence or absence of the pathogen. However, the recently developed real-time PCR assay can be used to determine the amount of target DNA in a sample (17). We believe that the highly sensitive PCR assays and primers developed in this research will be a basis for future studies using real-time PCR to determine the levels of A. morbosa in plant tissues. Such future work will involve applying the specific primers AMF and AMR to detect the concentrations of pathogen DNA at different distances from black knots using the real-time PCR technique. Furthermore, the spore density carried on plant surfaces may be determined by the real-time PCR technique. The information obtained from real-time PCR has the potential to enhance the accuracy of black knot disease surveillance and increase our understanding of the epidemiology of the hostpathogen interaction in the field.

\section{ACKNOWLEDGMENTS}

This research was supported by a grant from the Agri-Food Research and Development Initiative (ARDI) Canada and royalties generated by the Potentilla cultivar 'Pink Beauty' developed in the 
Department of Plant Science, University of Manitoba. We also thank Jeffries Nurseries, Portage La Prairie, Manitoba, for their interest and participation in the project.

\section{LITERATURE CITED}

1. Chiang, Y. C., Chou, C. H., Lee, P. R., and Chiang, T. Y. 2001. Detection of leafassociated fungi based on PCR and nucleotide sequence of the ribosomal internal transcribed spacer (ITS) in Miscanthus. Bot. Bull. Acad. Sin. 42:39-44.

2. Duncan, J. M., Cooke, D., Birch, P., and Toth, R. 1998. Molecular variability in sexually reproducing fungal plant pathogens. Pages 19-39 in: Molecular Variability of Fungal Pathogens. P. D. Bridge, Y. Couteaudier, and J. M. Clarkson, eds. CAB International, Wallingford, U.K.

3. Edel, V. 1998. Polymerase chain reaction in mycology. Pages 1-20 in: Applications of Polymerase Chain Reaction in Mycology. P. D. Bridge, D. K. Aroa, C. A. Reddy, and R. P. Elander, eds. CAB Publishing, New York.

4. Förster, H., and Adaskaveg, J. E. 2000. Early brown rot infections in sweet cherry fruit are detected by Monilinia-specific DNA primers. Phytopathology 90:171-178.

5. Henson, J. M., and French, R. 1993. The polymerase chain reaction and plant disease diagnosis. Annu. Rev. Phytopathol. 31:81-109.

6. Jaeger, E. E. M., Carroll, N. M., Choudhury, S., Dunlop, A. A. S., Towler, H. M. A., Matheson, M. M., Adamson, P., Okhravi, N., and Lightman, S. 2000. Rapid detection and identification of Candida, Aspergillus, and Fusarium species in ocular samples using nested PCR. J. Clin. Microbiol. 38:2902-2908.

7. Klein, P. G., and Juneja, V. K. 1997. Sensitive detection of viable Listeria monocytogenes by reverse transcription-PCR. Appl. Environ. Microbiol. 63:4441-4448.

8. Koch, L. W. 1933. Investigations on black knot of plums and cherries I. Development and discharge of spores and experiments in control. Sci. Agric. 13:576-590.

9. Koch, L. W. 1934. Studies on the overwintering of certain fungi parasitic and saprophytic on fruit trees. Can. J. Res. 11:190-206.

10. Koch, L. W. 1935. Investigations on black knot of plums and cherries IV. Studies in pathogenicity and pathological histology. Sci. Agric. 15:729-743.

11. Lee, S. B., White, T. J., and Taylor, J. W. 1993. Detection of Phytophthora species by oligonucleotide hybridization to amplified ribosomal DNA spacers. Phytopathology 83:177-181.

12. Lodhi, M. A., Ye, G. N., Weeden, N. F., and Reisch, B. I. 1994. A simple and efficient method for DNA extraction from grapevine cultures and Vitis species. Plant Mol. Biol. Rep. 12:6-13.

13. McFadden-Smith, W., Northover, J., and Sears, W. 2000. Dynamics of ascospore release by Apiosporina morbosa from sour cherry black knots. Plant Dis. 84:45-48.

14. Northover, J., and McFadden-Smith, W. 1995. Control and epidemiology of Apiosporina morbosa of plum and sour cherry. Can. J. Plant Pathol. 17:57-68.

15. Shapira, R., Paster, N., Eyal, O., Menasherov,
M., Mett, A., and Salomon, R. 1996. Detection of aflatoxigenic molds in grains by PCR. Appl. Environ. Microbiol. 62:3270-3273.

16. Sinclair, W., Lyon, H., and Johnson, W. 1987. Black knot of Prunus. Page 152 in: Disease of Trees and Shrubs. Comstock Publishing Associates, Ithaca and London, Cornell University Press.

17. Taylor, G., Wang, X., and Jabaji-Hare, S. H 2003. Detection of the mycoparasite Stachybotrys elegans, using primers with sequencecharacterized amplification regions in conventional and real-time PCR. Can. J. Plant Pathol. 25:49-61.

18. Ward, E., and Adams, M. J. 1998. Analysis of ribosomal DNA sequences of Polymyxa species and related fungi and the development of genus and species-specific PCR primers. Mycol. Res. 102:965-974.

19. Ward, E., and Bateman, G. L. 1999. Comparison of Gaeumannomyces and Phialophora-like fungal pathogens from maize and other plants using DNA methods. New Phytol. 141:323331.

20. White, T. J., Bruns, T., Lee, S. B., and Taylor, J. 1990. Amplification and direct sequencing of fungal ribosomal RNA genes for phylogenetics. Pages 315-322 in: PCR Protocols: A Guide to Methods and Applications. M. A. Innis, D. H. Gelfand, J. J. Sninisky, and T. J. White, eds. Academic Press, San Diego, CA.

21. Wysong, D. S., and Harrell, M. O. 1986. Black knot of cherry and plum. Pages 70-71 in: Forest Nursery Diseases in the United States. U.S. Dep. Agric. For. Serv. Agric. Handb. 